\title{
Typing of Clostridium difficile strains by PCR-amplification of variable length 16S-23S rDNA spacer regions
}

\author{
VOLKER GÜRTLER* \\ Department of Microbiology, Heidelberg Repatriation Hospital, West Heidelberg, Australia
}

(Received 6 July 1993; accepted 14 July 1993)

\begin{abstract}
To develop a rapid and accurate method of typing large numbers of clinical isolates of Clostridium difficile, four regions of the rRNA operon [A, 15-1407 and B, 907-1407 (16S-16S); C, 1392-507 and D, 907-507 (16S-23S)] were enzymically amplified from 24 strains. When region A was hybridized to HindIII-digested genomic DNA isolated from $C$. difficile strains, all of the variable length restriction fragments hybridized. When region $B$ was hybridized to HindIII-digested genomic DNA isolated from $C$. difficile strains, a set of variable length restriction fragments (Group II) hybridized predominantly. When region $\mathrm{C}$ was separated by agarose gel electrophoresis, a series of products ranging in size from approximately 800-1300 bp was obtained. When regions $C$ and $D$ were digested with HindIII, a constant region of $430 \mathrm{bp}$ was found in both products and in all strains. From the above experiments it was concluded that the variable length Group II restriction fragments and the variable length region $\mathrm{C}$ amplification products were due to variable length $16 \mathrm{~S}-23 \mathrm{~S}$ spacer regions between alleles of the one strain. When region $C$ amplification products were separated by denaturing PAGE, 16 variable length rRNA alleles ( $r$ rnA-P) were demonstrated from $24 C$. difficile strains ranging in size from 852-1210 bp. After analysis with maximum parsimony, the 24 strains were divided into 14 ribotypes. The product $C$ ribotypes and band sizes were stable after 14 single colony passages on horse blood agar plates and stable in vivo, since ribotype $G$ was isolated twice from one patient and ribotype $E$ was isolated three times from another patient (all on separate occasions). The ribotyping method described here has clear advantages over existing $C$. difficile typing methods; it has universal applicability, it is objective and is moderately rapid.
\end{abstract}

\section{Introduction}

Clostridium difficile is closely associated with pseudomembranous colitis and antibiotic-associated diarrhoea in man (Bartlett et al., 1978; George et al., 1978). Nosocomial colonization and disease caused by $C$. difficile has been demonstrated (Johnson et al., 1990; McFarland et al., 1989). A method which is sufficiently stable and analyses large numbers of isolates quickly and accurately would be invaluable for clinical epidemiological studies of $C$. difficile.

The methods which have been used to type $C$. difficile include toxin detection (Wust et al., 1982), isolation of plasmids (Clabots et al., 1988a, b; Mulligan et al., 1988; Wust et al., 1982), a bacteriophage/bacteriocin typing system (Sell et al., 1983), antibiotic susceptibility testing (Delmee \& Avesani, 1988), SDS-PAGE (Tabaqchali et al., 1984), immunoblotting (Heard et al., 1986), restriction endonuclease analysis (Wren \& Tabaqchali,

*Author for correspondence. Tel. +61 3 4962743; fax +613 4962178 .
1987) and Southern hybridization of the ribosomal RNA operon (Bowman et al., 1991). Molecular genetic methods are more discriminating than the above methods.

The rRNA operon is present in varying copy number in all bacteria with some regions highly conserved and others highly variable (Neefs et al., 1990). Consequently, when genomic DNA digested with a restriction enzyme is hybridized to rRNA operons, several bands are detected (Garnier et al., 1991). The Southern hybridization of rRNA operons (ribotyping) to detect restriction fragment length polymorphisms (RFLPs) between strains has been reported in many bacterial species including Salmonella typhi strains (Altwegg et al., 1989), E. coli strains (LiPuma et al., 1989), Xanthomonas maltophilia (Bingen et al., 1991), Legionella pneumophila strains (Harrison et al., 1992), and Staphylococcus spp. and subspp. (DeBuyser et al., 1992). However, Southern hybridization is slow and labour intensive.

The rRNA operon has a very high genetic stability and the length of the 16S rRNA gene is constant in all eubacteria (Neefs et al., 1990). The numerous bands 
Table 1. Source and properties of $C$. difficile strains

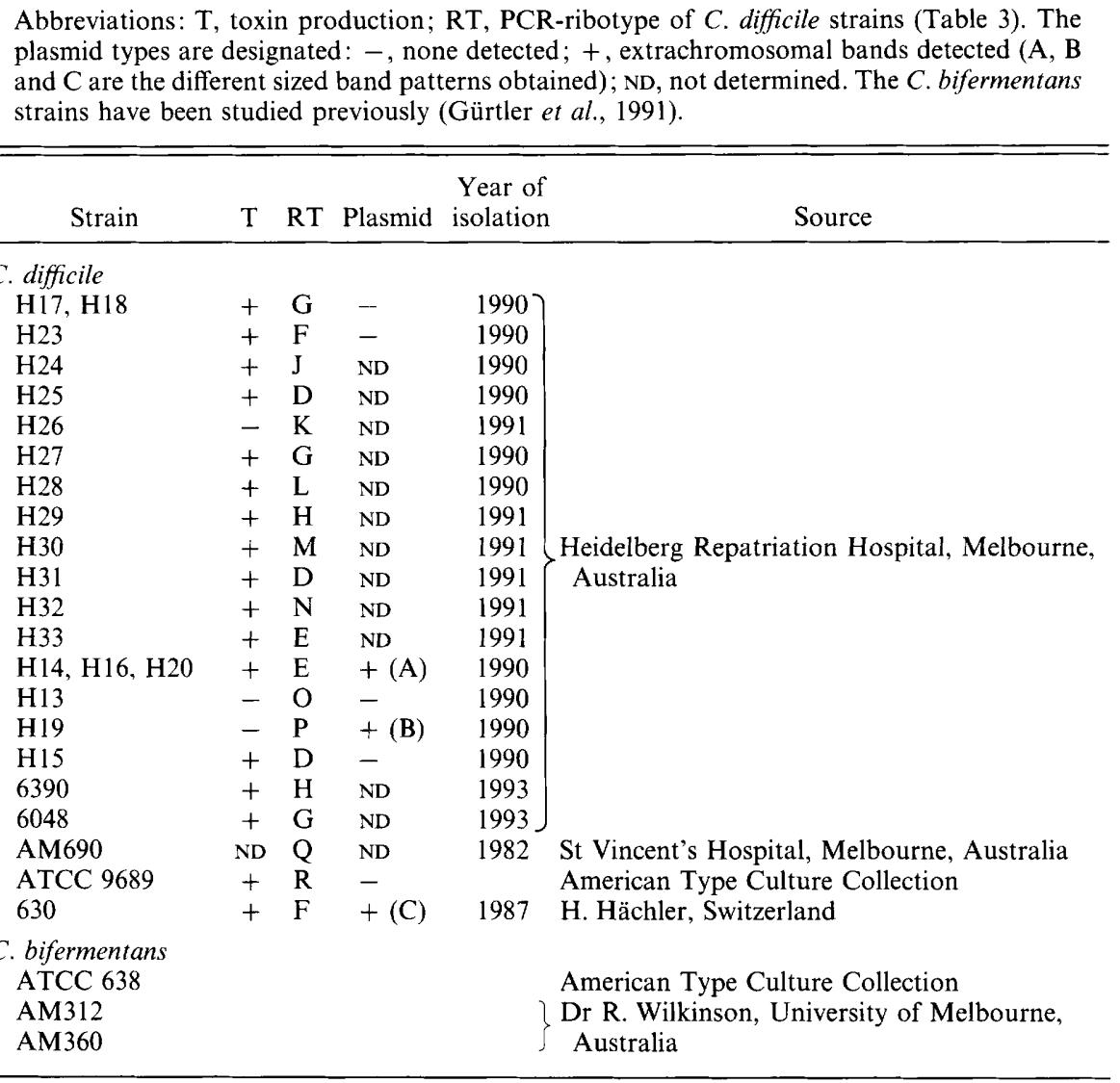

Table 2. Regions of the $r R N A$ operon amplified and their corresponding primers

The products amplified cover the regions shown where $S=16 \mathrm{~S}$ rRNA gene and $\mathrm{L}=23 \mathrm{~S}$ rRNA gene. The sense of the primers used is shown by $\mathrm{R}=$ reverse, $\mathrm{F}=$ forward and $*$ = identical region with $\mathrm{R} 1391$ being the complement of $\mathrm{R} 1391 \mathrm{~F}$. The positions of all the primers are in regions which are highly conserved in eubacteria (Neefs et al., 1990; Guttell \& Fox, 1988). The nucleotide numbering system is that of the E. coli operon (Brosius et al., 1978). The positions of each product are schematically represented in Fig. 1.

\begin{tabular}{|c|c|c|c|c|c|c|}
\hline $\begin{array}{c}\text { PCR } \\
\text { product }\end{array}$ & Gene & Region amplified & $\begin{array}{c}16 \mathrm{~S}-23 \mathrm{~S} \\
\text { spacer }\end{array}$ & $\begin{array}{l}\text { Primer } \\
\text { code }\end{array}$ & $\begin{array}{c}\text { Primer } \\
\text { position and } \\
\text { direction }\end{array}$ & Sequence \\
\hline \multirow[t]{2}{*}{ A } & $16 \mathrm{~S}$ & $15(\mathrm{~S})-1408(\mathrm{~S})$ & - & R015 & $15-27(\mathrm{~F})$ & GATCCTGGCTCAG \\
\hline & & & & R1391* & $1408-1391(\mathrm{R})$ & GACGGGCGGTGTGTACAA \\
\hline \multirow[t]{2}{*}{ B } & $16 \mathrm{~S}$ & $907(\mathrm{~S})-1408(\mathrm{~S})$ & - & R907 & $907-926(\mathrm{~F})$ & AAACTCAAATGAATTGACGG \\
\hline & & & & $\mathrm{R} 1391 *$ & $1408-1391(\mathrm{R})$ & GACGGGCGGTGTGTACAA \\
\hline \multirow[t]{2}{*}{$\mathrm{C}$} & $16 \mathrm{~S}$ and $23 \mathrm{~S}$ & $1392(\mathrm{~S})-507(\mathrm{~L})$ & + & $\mathrm{R} 1391 \mathrm{~F} *$ & $1391-1408(\mathrm{~F})$ & TTGTACACACCGCCCGTC \\
\hline & & & & LR488 & $488-507(\mathrm{R})$ & CCTTTCCCTCACGGTACTG \\
\hline \multirow[t]{2}{*}{$\mathrm{D}$} & $16 \mathrm{~S}$ and $23 \mathrm{~S}$ & $907(\mathrm{~S})-507(\mathrm{~L})$ & + & R907 & $907-926(\mathrm{~F})$ & AAACTCAAATGAATTGACGG \\
\hline & & & & LR488 & $488-507(\mathrm{R})$ & CCTTTCCCTCACGGTACTG \\
\hline
\end{tabular}

detected with ribotyping of $C$. difficile correspond to different rDNA alleles with variation in the regions flanking the 16S rRNA gene (Gürtler et al., 1991). The PCR-analysis of the 16S rRNA gene has been used to demonstrate species-specific differences (Gürtler et al., 1991) and strain differences (Vaneechoutte et al., 1992) in various bacterial species. Allelic species-specific dif- ferences within the 16S rRNA gene have been demonstrated in clostridia (Gürtler et al., 1991). The rRNA alleles of E. coli (Brosius et al., 1981) and B. subtilis (Loughney et al., 1982) have been shown to have variable length 16S-23S rRNA spacer regions. In this report evidence is provided to show that allelic differences seen in ribotyping of strains of $C$. difficile is explained by 


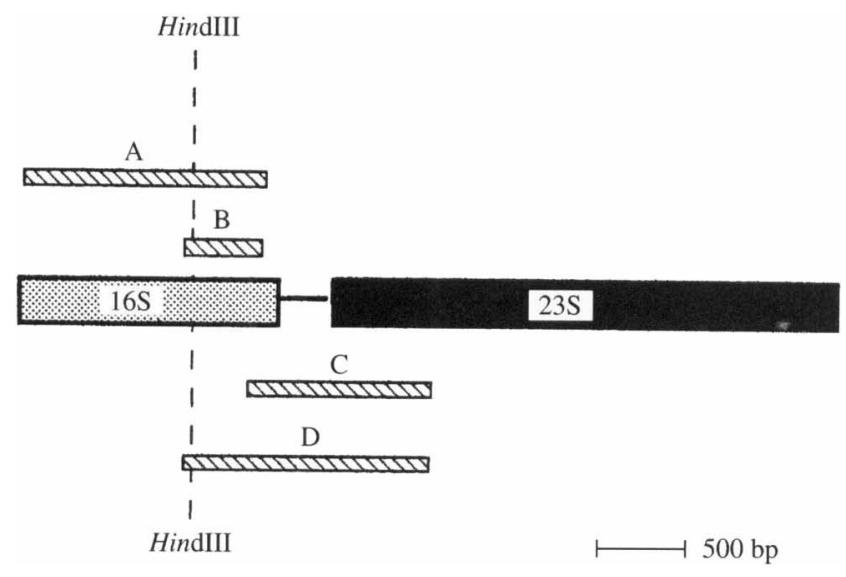

Fig. 1. Approaches used for the detection of rRNA alleles in $C$. difficile by Southern hybridization and PCR. The hatched bars (A, B, C and D) show positions of the respective PCR products (Table 2), the shaded bar denotes the 16S rRNA gene, the solid bar denotes the 23S rRNA gene, and the line joining the $16 \mathrm{~S}$ and $23 \mathrm{~S}$ genes depicts the spacer regions. The HindIII site is at position 975 of the 16S rRNA gene (Gürtler et al., 1991).

variable length $16 \mathrm{~S}-23 \mathrm{~S}$ rRNA spacer regions. A method is described which uses PCR to amplify the $16 \mathrm{~S}-23 \mathrm{~S}$ spacer region and demonstrate differences between $C$. difficile strains. The potential of this method in clinical epidemiology of $C$. difficile is discussed.

\section{Methods}

Bacterial strains. The bacterial strains used are listed in Table 1.

Cultivation. The identity of all strains was determined by biochemical tests (Cato et al., 1986) and confirmed by GLC (Sutter et al., 1985). Purified stocks were stored in cooked-meat broth at room temperature or in glycerol broth at $-20^{\circ} \mathrm{C}$. All strains were grown in brain heart infusion broth (BHI, Gibco). The stability of ribotype patterns was tested by passaging single colonies from horse blood agar plates every $2-3$ d over a 5 week period. Toxin B production by $C$. difficile strains was detected by the method of Boondeekhun et al. (1993)

DNA isolation. Genomic and plasmid DNA was isolated from all clostridia by the protocol of Gürtler et al. (1991).

DNA amplification. For DNA amplifications, the protocol of Gürtler et al. (1991) was followed with some modifications. The reaction volume and the amount of DNA were halved and 1.25 units Taq polymerase (Boehringer) was used. The regions that were amplified and their corresponding primers are shown in Table 2 .

Restriction enzyme analysis. Purified PCR products R907-LR507 and R1391-LR507 were digested singly or doubly with 10-15 units HindIII and CfoI, as instructed by the manufacturer (Boehringer). Genomic DNA was digested with 30 units HindIII. The digested and undigested PCR products were resolved on $2 \%(\mathrm{w} / \mathrm{v})$ low-gellingtemperature plus $2 \%(\mathrm{w} / \mathrm{v})$ 'AR' agarose gels. The HindIII-digested genomic DNA was resolved on $1 \%(\mathrm{w} / \mathrm{v})$ ' $A R$ ' agarose gels.

Southern hybridization. For hybridizations, the protocol of Gürtler $e t$ al. (1991) was followed with one exception. The PCR products A and B (Table 2) were amplified from $C$. difficile 630 and labelled with digoxigenin.

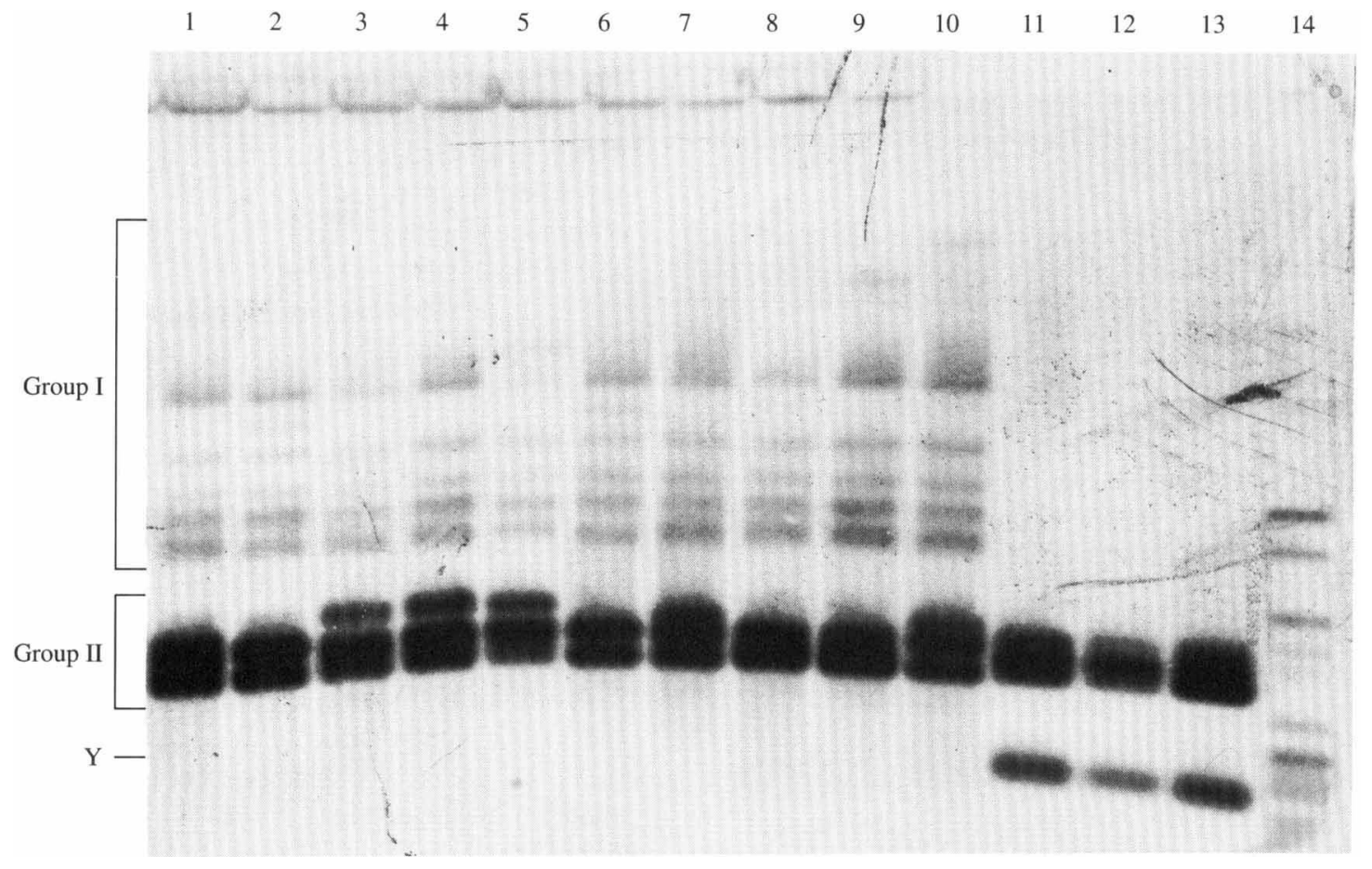

Fig. 2. Hybridization of PCR product B to Group II bands in genomic DNA isolated from C. difficile and C. bifermentans strains. Lanes: 1-10, C. difficile strains H13, H15, H16, H17, H18, H19, H20, H23, 9689 and 9689, respectively; 11-13, C. bifermentans strains AM312, AM360, and AM818, respectively; 14, pBR328 DNA digested with Bg/I and HinfI, labelled with photodigoxigenin. Y indicates the position of an extra band visible in $C$. bifermentans products. 


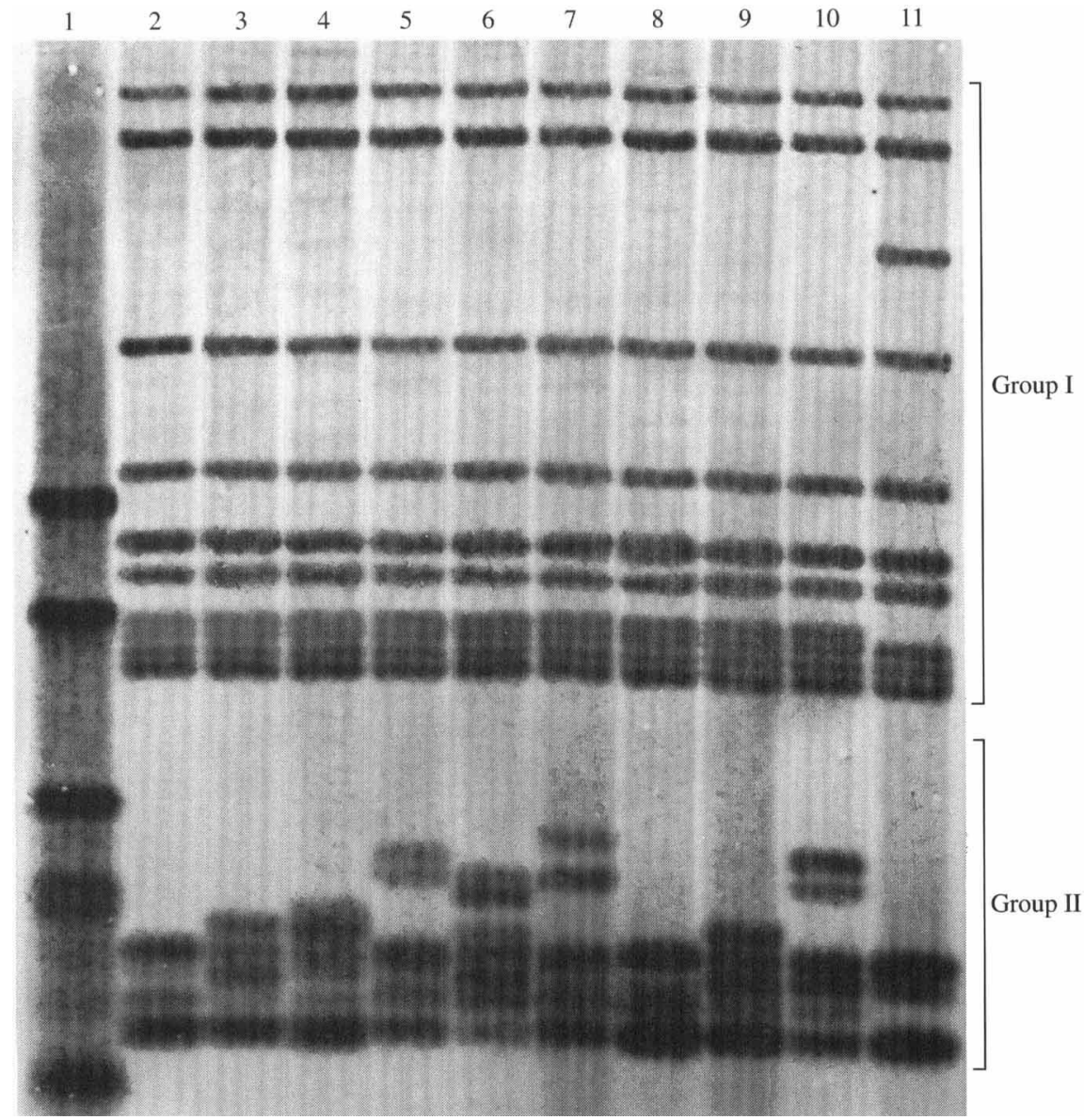

Fig. 3. Hybridization of PCR product A to Group I and II bands in genomic DNA isolated from $C$. difficile strains. Lanes: 1, pBR328 DNA digested with $B g / \mathrm{I}$ and $H i n f \mathrm{I}$, labelled with photodigoxigenin; 2-11, H24, H25, H26, H27, $\mathrm{H} 28, \mathrm{H} 29, \mathrm{H} 30, \mathrm{H} 31, \mathrm{H} 32$ and $\mathrm{H} 33$, respectively.
Denaturing PAGE. The above amplification protocol was followed with some modifications. The reaction volume was decreased by a factor of two and $2 \mu \mathrm{Ci}\left[\alpha{ }^{32} \mathrm{P}\right] \mathrm{dATP}$ (DuPont or Amersham) was added. The reduction of the cold dNTP's by a factor of four increased the yield of labelled product. Radiolabelled DNA fragments were separated on a $0.4 \mathrm{~mm}$ thick, $38 \mathrm{~cm}$ wide and $50 \mathrm{~cm}$ high (Bio-Rad), $3.5 \%(\mathrm{w} / \mathrm{v})$ polyacrylamide gel containing $7 \mathrm{M}$-urea (Sambrook et al., 1989). Gels were dried in a vacuum slab gel drier (Bio-Rad) for $2 \mathrm{~h}$ at $80{ }^{\circ} \mathrm{C}$. Autoradiography was for $18-96 \mathrm{~h}$.

Data analysis. The presence or absence of $\mathrm{PCR}$ product $\mathrm{C}$ bands was analysed by the following methods. (1) The presence or absence of bands (corresponding to region R1391-LR507) on autoradiograms was analysed by using the program BioImage (Millipore). The average sizes of the 16 alleles $(r r n \mathrm{~A}-\mathrm{P})$ were calculated from five separate gels ranging from 1-51 determinations for the respective alleles. Using these sizes as internal standards, molecular masses were assigned to respective bands from strains $630,9689, \mathrm{H} 14, \mathrm{H} 15$ or H23. Twenty-four strains from four gels were then compared at once. Presence or absence of bands was scored by a 1 or 0 , respectively. (2) The resulting data matrix prepared from four gels was analysed by maximum parsimony (Swofford, 1985).

\section{Results}

The DNA typing approaches used are shown in Fig. 1 and Table 2. Products A and B were hybridized to HindIII-digested genomic DNA isolated from C. difficile and $C$. bifermentans strains. Differences in HindIII sites on both flanking sides of the 16S rRNA gene were sought within and between strains. Products $\mathrm{C}$ and $\mathrm{D}$ were amplified from $C$. difficile strains in an attempt to find differences in the length of the $16 \mathrm{~S}-23 \mathrm{~S}$ spacer region within and between strains.

The bands detected by Southern hybridization (ribotyping) have been divided into Groups I and II, showing numerous Group II differences between strains and fewer Group I differences. Ribotyping of 21 isolates of $C$. difficile from the Heidelberg Repatriation Hospital and one from St Vincent's Hospital, Melbourne, Australia, produced 14 restriction fragment length polymorphism (RFLP) types, 10 of which are shown in Fig. 3. There were 10 group I bands (Fig. 3) demonstrating $10 \mathrm{rRNA}$ alleles in C. difficile.

Products A and B are comprised only of parts of the 16S rRNA gene (Table 2). It has been shown previously that the 16S rRNA gene is of constant length between alleles and strains of $C$. difficile (Gürtler et al., 1991). When PCR product B was hybridized to $C$. difficile genomic DNA, Group II bands hybridized predominantly (Fig. 2); the Group I bands hybridized faintly because product B included $62 \mathrm{bp} 5^{\prime}$ of the HindIII site 


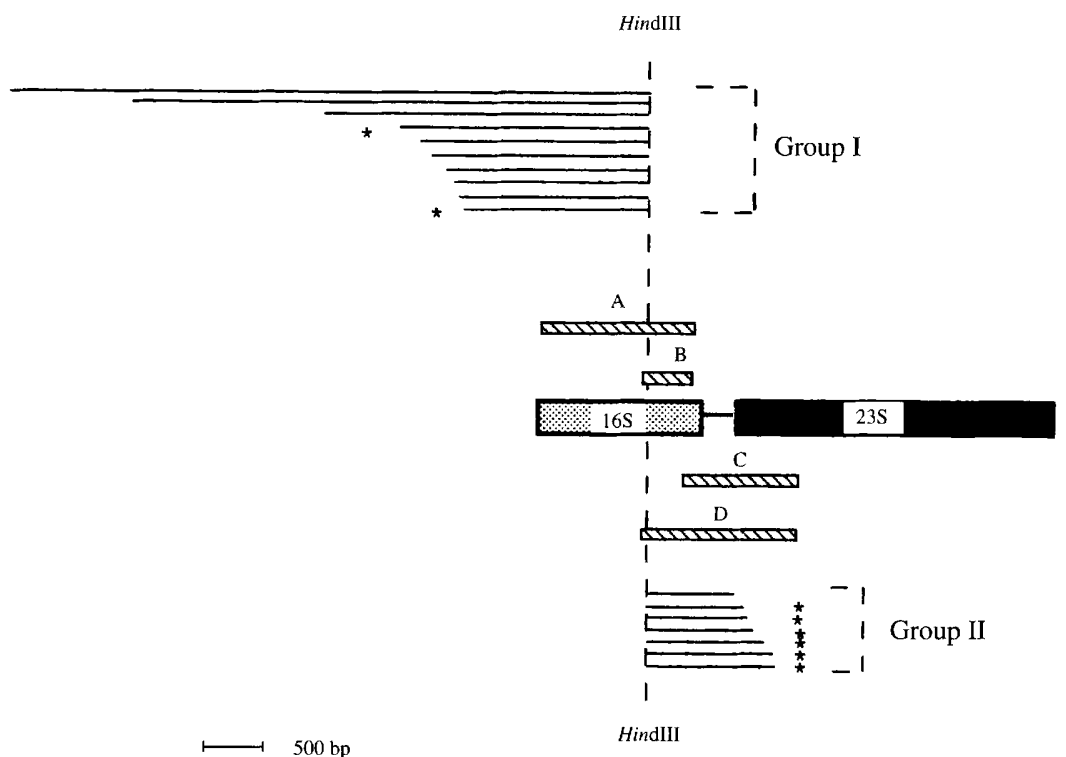

Fig. 4. Detection of rRNA alleles in $C$. difficile strains by Southern hybridization. The symbols, box shadings and the position of the HindIII site are described in the legend to Fig. 1. Bands depicted as Group I (Figs 3 and 4) correspond to fragments $5^{\prime}$ of the HindIII site and Group II bands (Figs 3 and 4) correspond to fragments $3^{\prime}$ of the HindIIl site. $\star$ refers to bands which are not present in all strains.

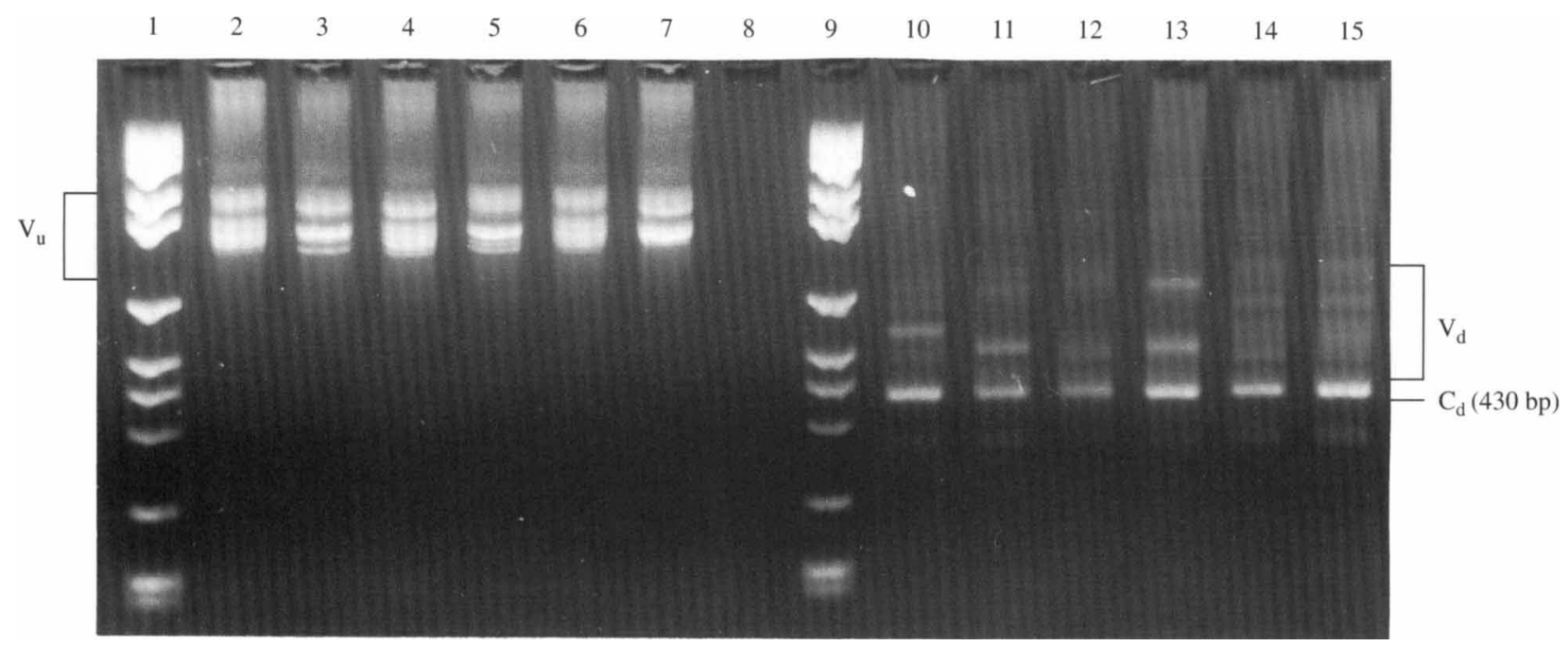

Fig. 5. Constant and variable length regions within PCR product $\mathrm{C}$ amplified from $C$. difficile strains. Agarose gel electrophoresis of undigested (lanes 2-7) and HindIII-digested (lanes 10-15) PCR product C. Lanes: 1, pBR328 DNA digested with HinfI and BglI; 2-7, $\mathrm{H} 15, \mathrm{H} 24, \mathrm{H} 28, \mathrm{H} 30, \mathrm{H} 31$ and H33, respectively; 8, no DNA control; 9, pBR328 DNA digested with HinfI and BglI; 10-15, H13, H14, $\mathrm{H} 17, \mathrm{H} 19, \mathrm{H} 23$ and 630 , respectively. The size of the standards are (in bp) $2176,1766,1230,1033,653,517,453,394,298,234$ and 220. $\mathrm{C}_{\mathrm{d}}$, constant HindIII-digested; $\mathrm{V}_{\mathrm{u}}$, variable undigested; and $\mathrm{V}_{\mathrm{d}}$, variable HindIII-digested.

(1/10 of product $B)$. When product $B$ was hybridized to C. bifermentans genomic DNA digested with HindIII (Fig. 2) no Group I bands hybridized and an extra band appeared (Y) due to an extra HindIII site at position 675 of the 16S rRNA gene (Gürtler et al., 1991). When PCR product A was used as a probe (Fig. 3), the Group I and II bands hybridized with equal intensity. The orientation of the Group I and II bands is as shown in Fig. 4 because (1) product B hybridized predominantly to Group II bands and (2) the HindIII site lies 62 bp downstream from the 5' end of product B (Gürtler et al., 1991).

From Figs 2, 3 and 4 it can be seen that the Group II bands are comprised of the spacer region and part of the 23S rRNA gene. These Group II bands were of variable length which could be explained by (1) a variable HindIII site or (2) an insertion within the spacer or the beginning of the 23S rRNA gene. To determine which possibility was correct, PCR products $\mathrm{C}$ and $\mathrm{D}$ were amplified, both of which include the spacer regions (Table 2). When the product $\mathrm{C}$ primer combinations were used (Table 2), several bands $\left(\mathrm{V}_{\mathrm{u}}\right)$ of varying molecular masses were obtained from each $C$. difficile strain (Fig. 5). The presence of bands varied from strain to strain. When $\mathrm{V}_{\mathrm{u}}$ bands were digested with HindIII, a band appeared at 
Table 3. Variable $16 S-23 S r R N A$ spacer regions in $C$. difficile strains

PCR product $\mathrm{C}$ was amplified from various $C$. difficile strains and separated by denaturing PAGE (Fig. 6). The presence of variable length alleles $(r n \mathrm{~A}-\mathrm{P})$ is shown. The size of each allele is shown in Fig. 6 . The outer limits of the constant regions is depicted by restriction enzyme-cut sites (see Figs 4 and 5). The strain numbers corresponding to the ribotype are listed in Table 1. The no. of isolates in each ribotype is listed below each letter. The constant length regions were collated from results obtained in Figs 2,3 and 5 and Gürtler et al. (1991). The variable length regions were collated (using BioImage software) from Fig. 6 and three other denaturing polyacrylamide gels.

\begin{tabular}{|c|c|c|c|c|c|c|c|c|c|c|c|c|c|c|c|c|c|}
\hline \multirow[b]{2}{*}{ Allele } & \multirow{2}{*}{\multicolumn{2}{|c|}{$\begin{array}{l}\text { Restriction } \\
\text { enzyme } \\
\text { site (position, } \\
\text { bp) }\end{array}$}} & \multicolumn{14}{|c|}{ C. difficile ribotype } & \multirow[b]{2}{*}{$\begin{array}{c}\text { Band } \\
\text { frequency* }\end{array}$} \\
\hline & & & $\begin{array}{l}Q \\
1\end{array}$ & $\begin{array}{l}\mathrm{L} \\
1\end{array}$ & $\begin{array}{l}\mathrm{D} \\
3\end{array}$ & $\begin{array}{l}E \\
4\end{array}$ & $\begin{array}{l}J \\
1\end{array}$ & $\begin{array}{c}\mathrm{N} \\
1\end{array}$ & $\begin{array}{l}\mathrm{G} \\
4\end{array}$ & $\begin{array}{l}\mathrm{F} \\
2\end{array}$ & $\begin{array}{l}\mathrm{O} \\
1\end{array}$ & $\begin{array}{l}\mathrm{P} \\
1\end{array}$ & $\begin{array}{c}\mathrm{K} \\
1\end{array}$ & $\begin{array}{c}\mathbf{H} \\
2\end{array}$ & $\begin{array}{c}M \\
1\end{array}$ & $\begin{array}{c}\mathrm{R} \\
1\end{array}$ & \\
\hline \multicolumn{18}{|c|}{$\begin{array}{l}\text { Constant region } \\
\text { (16S rRNA) }\end{array}$} \\
\hline All & HindIII & $(1010)$ & + & + & + & + & + & + & + & + & + & + & + & + & + & + & \\
\hline All & Cfol & $(1100 \dagger)$ & + & + & + & + & + & + & + & + & + & + & + & + & + & + & \\
\hline \multicolumn{18}{|c|}{$\begin{array}{c}\text { Variable region } \\
\text { (16S-23S spacer region) }\end{array}$} \\
\hline$r r n \mathrm{~A}$ & & & - & - & - & - & - & - & - & - & - & - & - & + & - & - & $8 \cdot 3$ \\
\hline$r r n \mathrm{~B}$ & & & - & - & + & + & + & + & + & + & + & - & + & + & + & + & $87 \cdot 5$ \\
\hline$r r n \mathrm{C}$ & & & - & - & - & - & - & - & + & - & - & - & - & - & - & - & $16 \cdot 7$ \\
\hline$r m \mathrm{D}$ & & & + & + & + & + & + & + & + & + & + & + & + & + & + & + & 100 \\
\hline$r r n \mathrm{E}$ & & & - & - & - & - & - & - & - & - & - & + & - & - & - & - & $4 \cdot 2$ \\
\hline $\operatorname{rrnF}$ & & & + & + & - & + & + & - & - & - & - & - & - & - & + & - & $33 \cdot 3$ \\
\hline$r r n \mathrm{G}$ & & & - & - & - & - & - & - & - & + & + & - & + & - & - & - & $16 \cdot 7$ \\
\hline$r r n \mathrm{H}$ & & & - & - & - & - & - & - & - & - & - & - & + & - & - & - & $4 \cdot 2$ \\
\hline$r r n \mathbf{I}$ & & & + & - & + & - & - & - & - & - & - & - & - & - & - & - & $16 \cdot 7$ \\
\hline$r r n \mathbf{J}$ & & & + & + & + & - & - & - & - & - & + & - & + & - & - & - & $29 \cdot 2$ \\
\hline$r r n \mathrm{~K}$ & & & - & - & - & - & - & - & - & + & - & - & - & - & - & - & $8 \cdot 3$ \\
\hline$r r n \mathrm{~L}$ & & & + & + & + & + & + & + & + & + & + & + & + & + & + & + & 100 \\
\hline$r r n \mathrm{M}$ & & & + & - & - & - & - & - & + & + & + & + & + & + & - & - & 50 \\
\hline$r r n \mathrm{~N}$ & & & - & + & + & + & t & + & - & - & - & + & + & - & - & - & 50 \\
\hline$r m \mathrm{O}$ & & & + & + & + & - & - & - & + & + & + & + & - & + & + & + & $70 \cdot 8$ \\
\hline \multirow[t]{2}{*}{$\operatorname{rrn} \mathrm{P}$} & & & - & + & + & - & + & + & + & - & + & + & + & + & + & + & $70 \cdot 8$ \\
\hline & \multicolumn{17}{|c|}{$\begin{array}{l}\text { Constant region } \\
(23 \mathrm{~S} \text { rRNA) }\end{array}$} \\
\hline All & HindIII & $(80)$ & + & + & + & + & + & + & + & + & + & + & + & + & + & + & \\
\hline
\end{tabular}

* Calculated by dividing the no. of isolates with allele $r r n$ by the total no. of isolates.

$\dagger$ Enzyme site reported previously (Gürtler et al., 1991).

$430 \mathrm{bp}\left(\mathrm{C}_{\mathrm{d}}\right)$ which was of higher intensity than the digested variable length bands, $V_{d}$. Band $C_{d}$ appeared in all the strains listed in Table 1 (not shown). When the product $\mathrm{D}$ primer combination was used, the same HindIII band $\left(\mathrm{C}_{\mathrm{d}}\right)$ was present (not shown) demonstrating that this band contains the $23 \mathrm{~S}$ rRNA gene from position 80-507 (Table 3). The demonstration of band $C_{d}$ shows that this region is of constant length between alleles. Taken with the Southern hybridization data (Figs 2 and 3) these results show that the variable length regions lie between the $16 \mathrm{~S}$ and $23 \mathrm{~S}$ rRNA genes. The exact base pair location of the spacer regions may only be determined when the separate alleles have been sequenced.

The resolution of the variable length bands was low (Fig. 5) and so it was decided to increase the resolution with long denaturing polyacrylamide gels. When this was done, the same amplification products $\left(V_{u}\right.$; Fig. 5) separated into between 5 and 9 bands per strain, with the presence of bands variable between strains (Fig. 6). Each band was assigned as an allele resulting in a total of 16 alleles (A-P) of variable length (Fig. 6). The constant length regions within the $16 \mathrm{~S}$ and $23 \mathrm{~S}$ genes were partially characterized (Table 3 ). The variability in length was due to variable length $16 \mathrm{~S}-23 \mathrm{~S}$ spacer regions between alleles.

When all of the $C$. difficile strains listed in Table 1 were analysed, 24 strains were divided into 14 ribotypes (Table 3 ). A dendrogram is shown in Fig. 7 showing 3 clusters $(a, b, c)$ found in all trees analysed. Within ribotype $\mathrm{G}, 2$ isolates were cultured from one patient at different times; within ribotype E, 3 isolates were cultured from one patient at different times. All other isolates which had identical patterns (ribotypes D, E, F, G and H) were from different patients.

The stability of band $V_{o}$ sizes and patterns was 

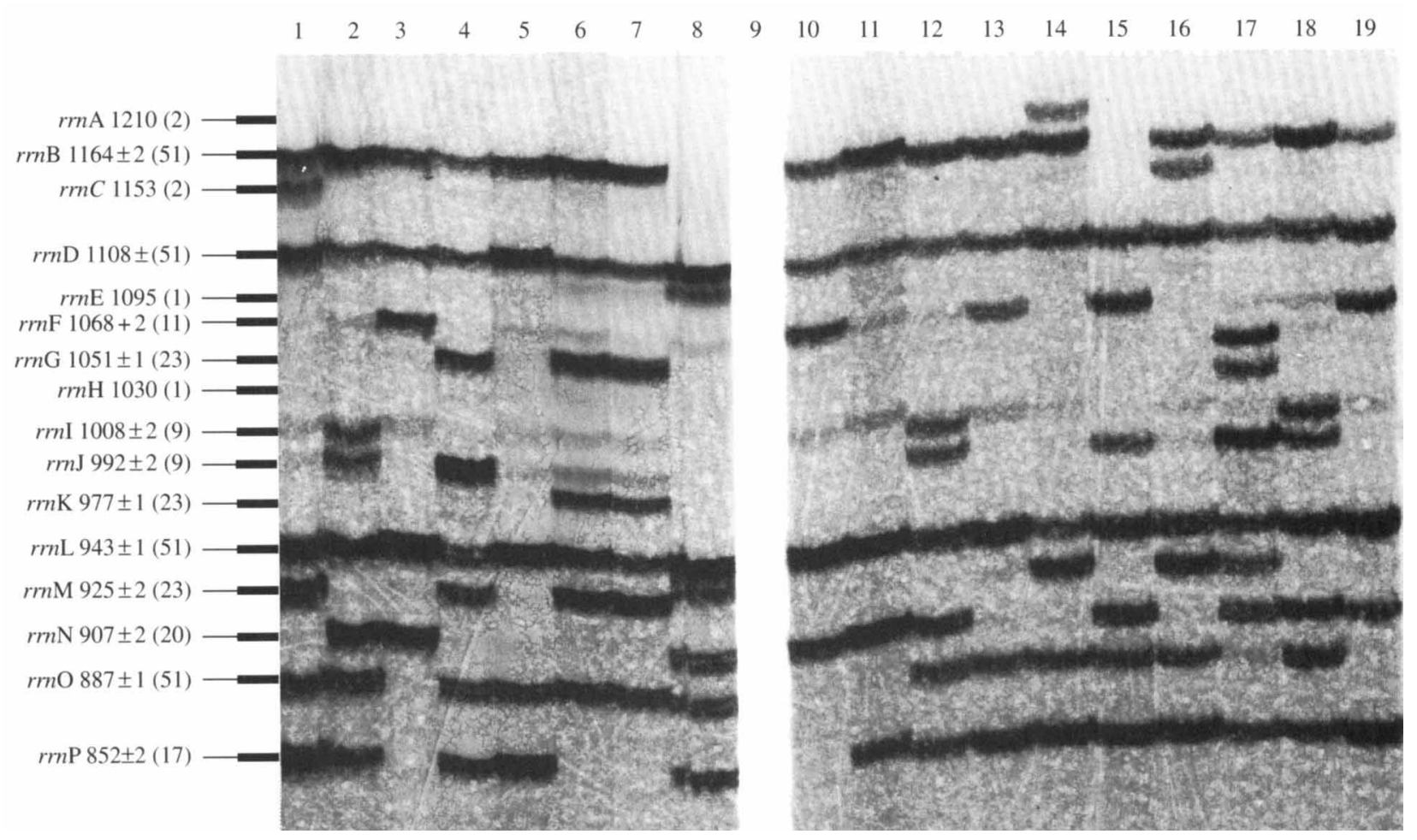

Fig. 6. Denaturing PAGE of PCR product $C$ amplified from strains of $C$. difficile. Lanes: 1-8, H17, H15, H14, H13, 9689, 630, H23 and H19, respectively; 9, no DNA PCR control; 10-19, H33, H32, H31, H30, H29, H28, H27, H26, H25 and H24, respectively. The sizes of the respective alleles are shown on the left [mean \pm SEM (number of determinations)]. The molecular mass markers used (not shown) were $\lambda$ DNA digested with HindIII and EcoRI ( 947 and 831 bp bands only) and SPPI DNA digested with EcoRI (1150 and $1000 \mathrm{bp}$ bands only).

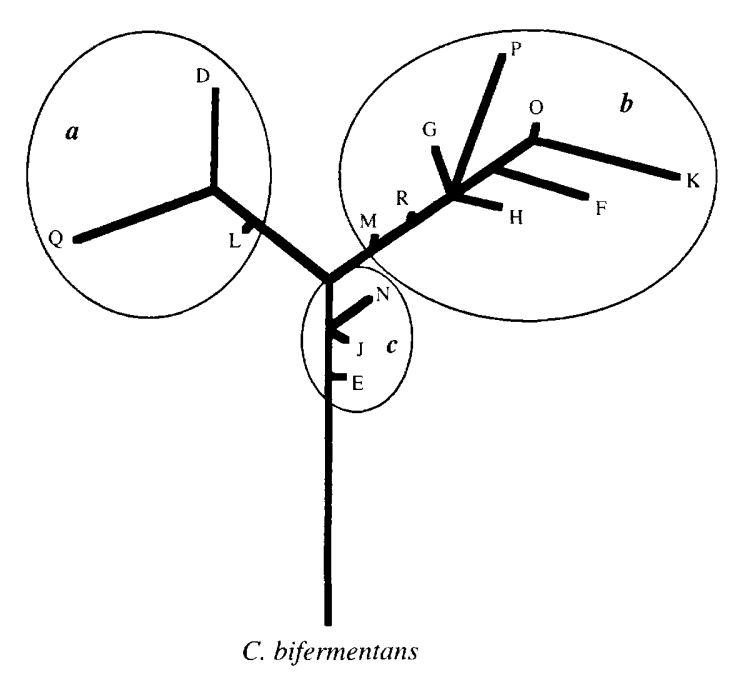

Fig. 7. Dendrogram showing the relationships of $C$. difficile ribotypes. Using maximum parsimony, 50 equally parsimonious trees were found, one of which is shown. The same ribotypes were found in each of the circled branches $(a, b, c)$ for all 50 trees. The root of the tree $(C$. bifermentans) had no bands in common with any of the ribotypes.

investigated in detail by passaging five strains over a 5 week period (Table 4). The alleles were scored as positive or negative by appearing visually identical and by having similar calculated molecular masses (Fig. 6 and Table 4). The results show that both the band sizes and patterns were highly reproducible in five $C$. difficile strains. The band sizes and patterns of strains $\mathrm{H} 23$ and 630 were reproducibly identical.

\section{Discussion}

The main finding of the present study was that the presence or absence of specific variable length rDNA spacer regions varied between $C$. difficile strains. The patterns obtained were stable within strains upon repeated testing (with passaging in vitro and in vivo), allowed the designation of strains to specific types, discriminated within and between species, and allowed for the easy testing of large numbers of strains. With these criteria met, the novel molecular typing method described here may be applied to epidemiological studies of $C$. difficile.

Since $500 \mathrm{bp}$ of the $5^{\prime}$ end of the $23 \mathrm{~S}$ gene was amplified, it was possible that the observed heterogeneity of PCR products was due to an insertion within the first $500 \mathrm{bp}$ of the $23 \mathrm{~S}$ gene. In support of this possibility are the following studies: (1) at least one extra cleavage site has been reported in the large rRNA subunit of 
Table 4. Stability of product $C$ bands from $C$. difficile strains

Product $\mathrm{C}$ was amplified from various $C$. difficile strains and separated by denaturing PAGE. Accumulated values (mean \pm SEM) taken from five separate electrophoresis runs are shown. The data include runs (PCR, DNA preparations and electrophoresis) done over a 9 month period, as well as a stability testing experiment with the no. of single colony passages per strain shown.

\begin{tabular}{|c|c|c|c|c|c|}
\hline \multirow[b]{2}{*}{ Allele } & \multicolumn{5}{|c|}{ Strain } \\
\hline & 630 & 9689 & $\begin{array}{c}\mathrm{H} 14 \\
\text { (type E) }\end{array}$ & $\begin{array}{c}\text { H15 } \\
\text { (type D) }\end{array}$ & $\begin{array}{c}\mathrm{H} 23 \\
\text { (type F) }\end{array}$ \\
\hline \multicolumn{6}{|l|}{$r r n \mathrm{~A}$} \\
\hline$r r n \mathrm{~B}$ & $1166 \pm 3$ & $1163 \pm 4$ & $1164 \pm 4$ & $1163 \pm 5$ & $1161 \pm 4$ \\
\hline$r m \mathrm{D}$ & $1108 \pm 2$ & $1110 \pm 4$ & $1106 \pm 3$ & $1108 \pm 4$ & $1106 \pm 3$ \\
\hline \multicolumn{6}{|l|}{$r r n \mathrm{E}$} \\
\hline$r r n \mathrm{~F}$ & & & $1068 \pm 2$ & & \\
\hline $\begin{array}{l}\operatorname{rrnG} \mathrm{G} \\
\operatorname{rrn} \mathrm{H}\end{array}$ & $1050 \pm 2$ & & & & $1052 \pm 2$ \\
\hline$r m \mathrm{I}$ & & & & $1008 \pm 2$ & \\
\hline$r r n \mathrm{~J}$ & & & & $992 \pm 2$ & \\
\hline \multicolumn{6}{|c|}{$978 \pm 2$} \\
\hline$r r n \mathrm{~L}$ & $945 \pm 3$ & $937 \pm 2$ & $948 \pm 3$ & $943 \pm 3$ & $938 \pm 2$ \\
\hline$r r n \mathrm{M}$ & $928 \pm 3$ & & & & $922 \pm 2$ \\
\hline$r r n \mathrm{~N}$ & & & $908 \pm 3$ & $906 \pm 3$ & \\
\hline$r m \mathrm{O}$ & $890 \pm 3$ & $884 \pm 1$ & & $887 \pm 3$ & $885 \pm 1$ \\
\hline $\operatorname{rrn} \mathrm{P}$ & & $851 \pm 1$ & & $853 \pm 3$ & \\
\hline \multicolumn{6}{|l|}{ Statistics } \\
\hline$n$ & 14 & 8 & 11 & 9 & 9 \\
\hline $\begin{array}{l}\text { DNA } \\
\text { preparations }\end{array}$ & 5 & 5 & 4 & 4 & 5 \\
\hline Passages & 14 & 14 & 10 & 10 & 14 \\
\hline PCR runs & 10 & 5 & 4 & 4 & 6 \\
\hline
\end{tabular}

Leptospira interrogans (Hsu et al., 1990) and Salmonella spp. (Hsu et al., 1992), producing several fragments smaller than 23S; and (2) a $90 \mathrm{bp}$ intervening sequence has been shown to be excised during large subunit rRNA maturation (Burgin et al., 1990). The results presented in this report show that in $C$. difficile, $430 \mathrm{bp} 3^{\prime}$ from position 507 of the 23S rRNA gene was of constant length and the $16 \mathrm{~S}-23 \mathrm{~S}$ spacer DNA was of variable length between alleles.

The 16S-23S spacer regions of B. subtilis (Vold, 1985) and E. coli (Fournier \& Ozeki, 1985) contain tRNA genes which vary in length from $75-90 \mathrm{bp}$. Of the $7 \mathrm{rrn}$ operons in $E$. coli all contain from 1-3 tRNA genes (Brosius et al., 1981), while in B. subtilis, of the $10 \mathrm{rrn}$ operons, two out of the three analysed sets have been shown to contain tRNA genes (Loughney et al., 1982). It is possible that the $16 \mathrm{~S}-23 \mathrm{~S}$ spacer regions in $C$. difficile characterized herein may contain tRNA genes.

Of the numerous typing methods which have been used in the epidemiology of $C$. difficile all have some disadvantages. The separation of $\left[{ }^{35} \mathrm{~S}\right]$ methioninelabelled proteins by PAGE (Tabaqchali et al., 1984) has divided 245 strains of $C$. difficile into 15 distinct types
(Tabaqchali, 1990). The current method has the potential to separate strains into more types with 24 strains divided into 14 types. The bacteriophage/bacteriocin typing scheme of Sell et al. (1983) has been used to type $114 C$. difficile isolates producing 31 typing patterns (Mahony et al., 1991), however, only 16-40\% were typeable. The detection of plasmids has been used to type C. difficile isolates; however, the percentages of isolates which have plasmids varies from $18 \%$ (Muldrow et al., 1982) to $59 \%$ (Mahony et al., 1991). The present study found that three strains were not plasmid-typeable since no plasmids were detected (Table 1). The detection of cytotoxin (Wust et al., 1982) is of limited value since only positive or negative production is measured; the present study also demonstrates this drawback. The large number of bands obtained with HindIII restriction endonuclease analysis of total DNA (Wren \& Tabaqchali, 1987) makes this method difficult to interpret. Finally, Southern hybridization of rRNA genes (Bowman et al., 1991; and this study) lacks resolution and is time consuming.

The present study has demonstrated a typing approach for $C$. difficile based on variable length $16 \mathrm{~S}-23 \mathrm{~S}$ rRNA spacer regions. The variability of the spacer regions between strains makes this method potentially useful in epidemiological studies. It does not have any of the disadvantages of the above methods making it the most promising method available.

I would like to thank Dr B. C. Mayall and Ms V. A. Wilson for helpful discussions. The technical assistance of Mrs H. D. Barrie is appreciated. I thank Drs R. Wilkinson and H. Hächler for supplying me with bacterial strains. I would like to thank the Department of Veterans' Affairs for permission to publish this paper.

\section{References}

Altwegg, M., Hickmann-Brenner, F. W. \& Farmer, J. J., III (1989). Ribosomal RNA gene restriction patterns provide increased sensitivity for typing Salmonella typhi strains. Journal of Infectious Diseases 160, 145-149.

Bartlett, J. G., Chang, T. W., Gurwith, M., Gorbach, S. L. \& ONDERDONK, A. B. (1978). Antibiotic-associated pseudomembranous colitis due to toxin-producing clostridia. New England Journal of Medicine 298, 531-534.

Bingen, E. H., Denamur, E., Lambert-Zechvosky, N. Y., Bourdois, A., Mariani-Kurkdjian, P., Cezard, J.-P., Navarro, J. \& Elion, J. (1991). DNA restriction fragment length polymorphism differentiates crossed from independent infections in nosocomial Xanthomonas maltophilia bacteremia. Journal of Clinical Microbiology 29, $1348-1350$

Boondeekhun, H. S., Gürtler, V., Odd, M. L., Wilson, V. A. \& MaYall, B. C. (1993). Detection of the Clostridium difficile enterotoxin gene in clinical specimens by the polymerase chain reaction. Journal of Medical Microbiology 38, 384-387.

Bowman, R. A., O'Neill, G. L. \& Riley, T. V. (1991). Nonradioactive restriction fragment length polymorphism (RFLP) typing of Clostridium difficile. FEMS Microbiology Letters 63, 269-272.

Brosius, J., Palmer, M. L., Kennedy, P. J. \& Noller, H. F. (1978) Complete nucleotide sequence of a $16 \mathrm{~S}$ ribosomal RNA gene from 
Escherichia coli. Proceedings of the National Academy of Sciences of the United States of America 72, 4801-4805.

Brosius, J., Dull, T. J., Sleeter, D. D. \& Noller, H. F. (1981). Gene organization and primary structure of a ribosomal RNA operon from Escherichia coli. Journal of Molecular Biology 148, 107-127.

Burgin, A. B., Parodos, K., Lane, D. J. \& Pace, N. R. (1990). The excision of intervening sequences from Salmonella $23 \mathrm{~S}$ ribosomal RNA. Cell 60, 405-414.

Cato, E. P., George, W. L. \& Finegold, S. M. (1986). Genus Clostridium Prazmowski $1880,23^{\mathrm{AL}}$. In Bergey's Manual of Sy:Stematic Bacteriology, vol. 2, pp. 1141-1200. Edited by P. H. A. Sneath, N. S. Mair, M. E. Sharpe \& J. G. Holt. Baltimore: Williams $\&$ Wilkins.

Clabots, C., Lee, S., Gerding, D., Mulligan, M., Kwok, R., Schaberg, D., Fekety, R. \& Peterson, L. (1988a). Clostridium difficile plasmid isolation as an epidemiologic tool. European Journal of Clinical Microbiology and Infectious Diseases 7, 312-315.

Clabots, C. R., Peterson, L. R. \& Gerding, D. N. (1988b). Characterization of a nosocomial Clostridium difficile outbreak by using plasmid profile typing and clindamycin susceptibility testing. Journal of Infectious Diseases 158, 731-736.

De Buyser, M.-L., Morvan, A., Aubert, S., Dilasser, F. \& El Sohl, N. (1992). Evaluation of a ribosomal RNA gene probe for the identification of species and subspecies within the genus Staphylococcus. Journal of General Microbiology 138, 889-899.

Delmee, M. \& Avesani, V. (1988). Correlation between serogroup and susceptibility to chloramphenicol, clindamycin, erythromycin, rifampicin and tetracycline among 308 isolates of Clostridium difficile. Journal of Antimicrobial Chemotherapy 22, 325-331.

FoURNIER, M. J. \& OZEKI, H. (1985). Structure and organization of the transfer ribonucleic acid genes of Eschericia coli K-12. Microbiological Review's 49, 379-397.

Garnier, T., Canard, B. \& Cole, S. T. (1991). Cloning, mapping, and molecular characterization of the rRNA operons of Clostridium perfringens. Journal of Bacteriology 173, 5431-5438.

George, R. H. S., Symonds, J. M., Dimock, F., Brown, J. D., Arabi, Y., Shinagawa, N., Keighley, M. R. B., Alexander-Williams, J. \& Burdon, D. W. (1978). Identification of Clostridium difficile as a cause of pseudomembranous colitis. British Medical Journal 1, 695.

Gürtler, V., Wilson, V. A. \& MAYAll, B. C. (1991). Classification of medically important clostridia using restriction endonuclease site differences of PCR-amplified 16S rDNA. Journal of General Microbiology 137, 2673-2679.

GutTell, R. R. \& Fox, G. E. (1988). A compilation of large sub-unit RNA sequences presented in a structural format. Nucleic Acids Research 16, r175-r269.

Harrison, T. G., Saunders, N. A., Haththotuwa, A., Doshi, N. \& TAYLOR, N. G. (1992). Further evidence that genotypically closely related strains of Legionella pneumophila can express different serogroup specific antigens. Journal of Medical Microbiology 37, 155-161.

Heard, S. R., Rasburn, B., Matthews, R. C. \& Tabaqchali, S. (1986). Immunoblotting to demonstrate antigenic and immunogenic differences among nine standard strains of Clostridium difficile. Journal of Clinical Microbiology 24, 384-387.

Hsu, D., Pan, M.-J., Zee, Y. C. \& Le Febvre, R. B. (1990). Unique ribosome structure of Leptospira interrogans is composed of four rRNA components. Journal of Bacteriology 172, 3478-3480.

Hsu, D., Zee, Y. C., Ingraham, J. \& Shih, L.-M. (1992). Diversity of cleavage patterns of Salmonella 23S rRNA. Journal of General Microbiology 138, 199-203.

Johnson, S., Clabots, C. R., Linn, F. V., Olson, M. M., Peterson, L. R. \& Gerding, D. N. (1990). Nosocomial Clostridium difficile colonisation and disease. Lancet 336, 97-100

Lipuma, J. J., Stull, T. L., Dasen, S. E., Pidcock, K. A., Kaye, D. \& KORZENIOWSKI, O. M. (1989). DNA polymorphisms among Escherichia coli isolated from bacteriuric women. Journal of Infectious Diseases 159, 526-532.

Loughney, K., Lund, E. \& Dahlberg, J. E. (1982). tRNA genes are found between the 16S and 23S rRNA genes in Bacillus subtilis. Nucleic Acids Research 10, 1607-1624

Mahony, D. E., Clow, J.. Atkinson, L., Vakharia, N. \& Schlech, W. F. (1991). Development and application of a multiple typing system for Clostridium difficile. Applied and Environmental Microbiology 57, 1873-1879.

McFarland, L. V., Mulligan, M. E., Kwok, R. Y. \& Stamm, W. E. (1989). Nosocomial acquisition of Clostridium difficile infection. New England Journal of Medicine 320, 204-210.

Muldrow, L. L., Archibold, E. R., Nunez, M. O. \& Sheehy, R. J. (1982). Survey of the extrachromosomal gene pool of Clostridium difficile. Journal of Clinical Microbiology 16, 637-640.

Mulligan, M. E., Peterson, L. R., Kwok, R. Y., Clabots, C. R. \& GERDING, D. N. (1988). Immunoblots and plasmid fingerprints compared with serotyping and polyacrylamide gel electrophoresis for typing Clostridium difficile. Journal of Clinical Microbiology $\mathbf{2 6}$, $41-46$.

Neefs, J.-M., Van de Peer, Y., Hendriks, L. \& De Wachter, R. (1990). Compilation of small ribosomal sub-unit RNA sequences. Nucleic Acids Research 18, r2237-r2317.

Sambrook, J., Fritsch, E. F. \& Maniatis, T. (1989). Molecular Cloning: A Laboratory Manual, 2nd edn. Cold Spring Harbor, NY: Cold Spring Harbor Laboratory.

Sell, T. L., Schaberg, D. R. \& Fekety, F. R. (1983). Bacteriophage and bacteriocin typing scheme for Clostridium difficile. Journal of Clinical Microbiology 17, 1148-1152.

Sutter, V. L., Citron, D. M., Edelstein, M. A. C. \& Finegold, S. M. (1985). Wadsworth Anaerobic Bacteriology Manual, 4th edn. Belmont, California: Star Publishing Company.

SwOFFORD, D. L. (1985). Phylogenetic analysis using parsimony (PAUP) version 2.4. University of Illinois.

TABaQCHali, S. (1990). Epidemiologic markers of Clostridium difficile. Reviews of Infectious Diseases 12 (suppl. 2), 192-199.

Tabaqchali, S., Holland, D., O'Farrell, S. \& Silman, R. (1984). Typing scheme for Clostridium difficile: its application in clinical and epidemiological studies. Lancet 1, 935-938.

Vaneechoutte, M., Rossau, R., De Vos, P., Gillis, M., Janssens, D., Paepe, N., De Rouck, A., Fiers, T., Clayes, G. \& Kersters, K. (1992). Rapid identification of bacteria of the Comamonadaceae with amplified ribosomal DNA-restriction analysis (ARDRA). FEMS Microbiology Letters 93, 227-234.

VOLD, B. S. (1985). Structure and organization of genes for transfer ribonucleic acid in Bacillus subtilis. Microbiological Reviews 49, 71-80.

WREN, B. W. \& TABAQCHALI, S. (1987). Restriction endonuclease DNA analysis of Clostridium difficile. Journal of Clinical Microbiology $\mathbf{2 5}$, $2402-2404$

Wust, J., Sullivan, N. M., Hardegger, U. \& Wilkins, T. D. (1982). Investigation of an outbreak of antibiotic-associated colitis by various typing methods. Journal of Clinical Microbiology 16, 1096-1101. 